Univerzitet Džemal Bijedić u Mostaru, Fakultet humanističkih nauka - Odsjek za engleski jezik i književnost,

Mostar, Bosna i Hercegovina

DOI 10.5937/kultura1757034R

UDK 821.163.4(497.6).09-1 Марић C.

originalan naučni rad

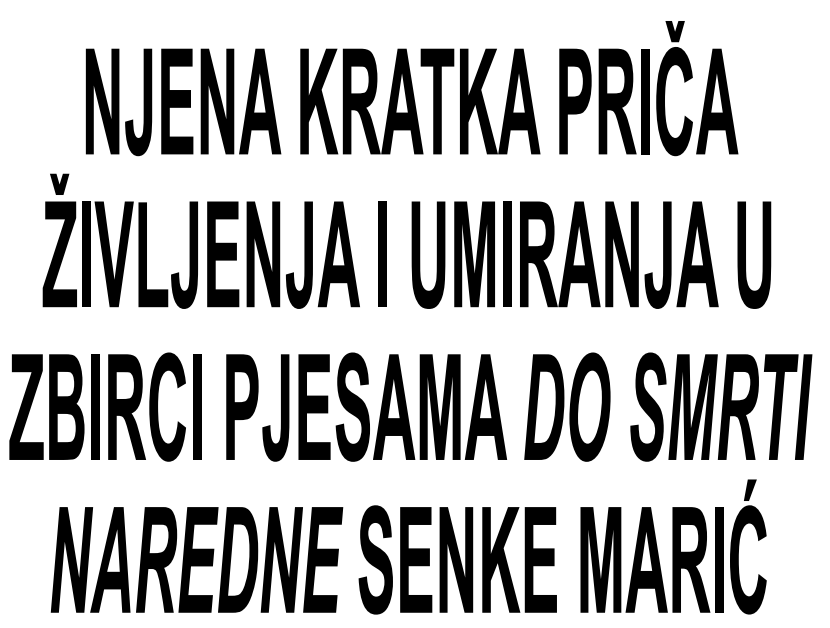

Sažetak: Senka Marić, priznata bosanskohercegovačka pjesnikinja, ispisuje "njenu" kratku priču ženskog življenja i umiranja u svojoj zbirci pjesama Do smrti naredne, objavljenoj 2016. godine. Nasuprot historiji viđenoj kao njegovoj priči (HIStory), što znači da historiju uglavnom pišu muškarci, njena priča (HERstory) otkriva žensku stranu svijeta kroz njenu ličnu priču. Do smrti naredne je umnogome autobiografska priča, pa ona funkcionira i kao poetski memoar Senke Marić. Njena geneza i kao pjesnikinje i kao žene je jedan od mnogih poetskih nivoa zbirke. Ona se, također, može vidjeti i kao lirski roman o ženskoj ontologiji. Shodno svemu tome, ovaj rad analizira koncepte ženskog bivanja i nebivanja u zbirci pjesama Do smrti naredne Senke Marić, kao $i$ elemente autobiografizacije i mitologizacije njene priče, uključujući $i$ elemente matrilinearnosti u svim tim nivoima.

Ključne riječi: Senka Marić, njena priča (herstory), Do smrti naredne, ženska ontologija, autobiografizacija, mitologizacija, matrilinearnost

Senka Marić je rođena u Mostaru pukim slučajem ${ }^{1}$, kako bi to rekao Benedikt Anderson (Benedict Anderson) u parafrazi riječi Režisa Debrea (Regis Debray). Taj puki slučaj Senku Marić čini pjesnikinjom koja pripada zamišljenoj zajednici ${ }^{2}$ grada Mostara

1 Anderson, B. (1998) Nacija: zamišljena zajednica, Beograd: Plato, str. 22. 2 Isto. 
i države Bosne i Hercegovine, nacije čiji se dio historije, te $z a$ mišljanja i stvaranja njene zajednice, mijenjao i u toku života pjesnikinje. Međutim, iako njen umjetnički izraz umnogome pripada univerzalnoj republici mašte 3 i književno nadilazi granice zamišljenih zajednica, pjesme uokvirene zbirkom začudnoga naslova Do smrti naredne nude i brojne lirske, kulturološke i ontološke slike koje svojim izvorom i utemeljenjem smještaju umjetnost riječi Senke Marić u širi kontekst kulturnih tradicija Evrope i u onaj uži, Hercegovine i Mostara, najdominantnijeg prostora njenih života. U svemu tome se, ipak, ta oznaka „njenih života“ izdvaja kao ključna. Naime, treća zbirka pjesama Senke Marić Do smrti naredne, objavljena 2016. godine, funkcionira, uvjetno rečeno, i kao njen poetski memoar i kao roman u stihovima ženskog lica. Do smrti naredne je, u svakom slučaju, knjiga o neminovnosti jednog ženskog, a opet i sveženskog i, na širem univerzalnom nivou, sveljudskog življenja i umiranja; knjiga o poetskoj genezi ženske duše i tijela; knjiga o ontologiji žene u bivanju i nebivanju; a onda, to je i autobiografska lirizacija matrilinearnosti; te, takoreći, apokrifni zapis o ženi savremenog doba; kao i eshatološki epitaf o specifično ženskim smrtima autentičnog ženskog pjesničkog iskustva, pri čemu su pjesme govor nad sopstvenim smrtima iz pozicije življenja i/ili preživljavanja do smrti naredne; i još mnogo toga. Ovim radom će se pokušati prikazati i analizirati slojevitost(i) priče ženskog subjekta, njena (hi)storija (herstory) življenja i umiranja u množini istih, odnosno zapis o ženi i zapis žene u zbirci pjesama $D o$ smrti naredne Senke Marić.

Naslov zbirke je netipičan i nesvakidašnji. On djeluje kao iskaz iskustva preživljene sopstvene smrti. Njime započinje lirska priča o jednom od života - nakon jednog, a prije drugog umiranja u cjelokupnom životu čovjeka, i to problematiziranog ženskog bića, a kao putovanju od rođenja kao prve stanice i smrti kao konačnog kraja puta, između čega se, na različitim stanicama, bezbrojno umire i ponovo rađa, svaki put na neki novi način. Ta priča je ženska ispovijest u slobodnom stihu. Pjesme su demistifikator složenih puteva ženskog postojanja u vizuri Senke Marić. Pjesnička (is)kazateljica govori izravno iz sebe, pa i onda kada je pjesnički iskaz u drugom ili trećem licu jednine, kao i u prvom ili trećem licu množine. Tom ogoljavanju sebstva u izrijeku života, čiji su sastavni dio nebrojene smrti do smrti konačne, između ostaloga, doprinosi i grafika pjesme, obnaženost lirskog postupka i odsustvo interpunkcije, i to pretežno na mjestima gdje bi rečenički znak trebao označiti određeni kraj. Paradoksalno, i pored toga što svaka naredna pjesma ima neku

3 Nafisi, A. (2014) The Republic of Imagination: America in Three Books, New York: Viking Penguin. 
unutarnju vezu s prethodnom, te posljednja pjesma u zbirci ne označava kraj, već je taj kraj životvorno otvoren, svaka pjesma izgleda kao da je baš ona posljednja, i to ujedno i prva i posljednja, isto kao što je i svaki dan, i svaki trenutak jednog života, na određen način, i prvi i posljednji. U svemu tome, jednu od neobičnosti pjesama Senke Marić u zbirci Do smrti naredne u odnosu na stvaralaštvo njene generacije, pregažene generacije, pa time i ovovremene izgubljene generacije u Mostaru i Bosni i Hercegovini, karakterizira nadilaženje rata. Njene pjesme se ne bave ratom. Njena poezija ne govori o posljednjem ratnom i poratnom preživljavanju u Bosnu i Hercegovini ili egzilu. Senka Marić se udaljava od toga. Jedna od preživljenih smrti u njenom životu je i smrt rata. Analogno tome, jedan od njenih prethodnih života u životu je i život rata. On se u istovremenom odsustvu i prisustvu tek osjeća u posljednjoj pjesmi pod naslovom „Dobro je“, čije riječi ispisuju i ljepotu i užas života kao zbira različitih života. Za nju je Senka Marić dobila titulu Evropske viteškinje poezije time što je 2013. godine pobijedila na Evropskom takmičenju za viteza/viteškinju poezije, koje okuplja pjesnike i pjesnikinje iz Austrije, Bosne i Hercegovine, Hrvatske, Italije, Mađarske, Slovačke i Slovenije. Zbog potke i pozicije te pjesme, cijelu zbirku, na određen način, opisuju riječi obrazloženja Odluke međunarodnog žirija toga takmičenja sa završne manifestacije održane u Mariboru, u novembru 2013. godine. U tom obrazloženju, između ostaloga, stoji da se autorica ne odriče „osobne i emotivne umiješanosti u pjesmu. Ona ne iscrtava paralele, nego jednostavno jukstaponira dva niza pjesničkih slika. Nešto neobično se događa u ovoj pjesmi. Ono što nije bilo izgovoreno, odjednom dobiva oblik: ovdje nema ni politike ni rata, ali istovremeno teško je ne pomisliti na nesreće koje ovo dvoje uzrokuje.“" Tu se, također, ističe da je pjesma Senke Marić „suptilna, sublimna i mudra. Ona je uspjela da 'poraste do jednostavnosti', kako bi rekao veliki grčki pjesnik Jorgos Seferis. “5 Ontološka jukstapozicija, ali i isprepletenost života i smrti, što na različitim nivoima pjesničkog iskaza prožima cijelu zbirku, sadržana je u naslovnom paradoksu pjesme „Dobro je“ slavenskog kulturološkog, često ironijskog izraza, za koji autorica prilikom jednog intervjua za Oslobođenje kaže: „,dobro je upravo zato što nije. "“ Ona dodaje:

\footnotetext{
4 Spirit of Bosnia / Duh Bosne br. 2, godište 9, 2. septembar 2017., http://www. spiritofbosnia.org/bs/volume-9-no-2-2014april/its-good/?output=pdf

5 Isto.

6 Salčinović, E. „Možda bismo odustali od ljubavi“: Intervju sa Senkom Marić, Oslobođenje, 6. februar 2017., 2. maj 2017., http://www.oslobodjenje.ba/ kun/umjetnost/mozda-bismo-odustali-od-ljubavi/193135.
} 
Mislim da nam sva (...) velika očekivanja, uvjerenost da smo predodređeni za sreću i da život trebaju činiti samo dobre stvari ne olakšavaju baš previše. Sklonija sam misliti da dobro i njegova suprotnost, kako god da je nazovemo, nisu dva pola, već samo dva isprepletena principa. Uvijek ćemo uz sve dobre stvari i gubiti, i bolovati, $i$ patiti. Lakše je kada smo u stanju to prihvatiti. ${ }^{7}$

Pjesmom „Dobro je“, dakle, završava priča u pjesmi Senke Marić Do smrti naredne. Ta priča uveliko govori o ljubavi, ali njene pjesme nisu ljubavne. One su fragmenti života koji se šuti. Drugim riječima, iz šutnje nastaju pjesme kao fragmenti iz života.

Sve počinje epigrafom u riječi pjesnikinje i/ili pjesničkog ženskog lica kazivanja kao apokrifnim zapisom prapočetka priče pjesama iz zbirke:

Za leđima mi je kameni zid. U ruci već boca ugrijane vode. Ispijam topli gutljaj i zatvaram oči. Ispod mene blješti more, plavetnilo koje je sposobno da pjeva. U daljini se naziru otoci, kao ostaci plastelina od kojeg je Bog pravio zemlju... ${ }^{8}$

Iako poezija Senke Marić intertekstualno vodi svojevrstan dijalog s religijskim tekstom, i to i s Kur'anom i Biblijom, smisao toga je tek poetski i, iznad svega, ljudski. Logika toga smisla, uvjetno rečeno, počiva u težnji za znanjem i potrebi za pronalaskom odgovora na pitanja na koja se odgovori ne mogu pronaći. Iz istog razloga njene pjesme razgovaraju i s umjetničkom riječi bosanskohercegovačkog pjesnika Maka Dizdara, češko-francuskog pisca Milana Kundere i makedonskog književnika Blaže Koneskog. Njena pjesnička ,ja“ intertekstualno komunicira i s Penelopom iz Homerove Odiseje, i s hazreti Fatimom, i s prvom ženom, pramajkom čovječanstva, i s mitskim, i mističnim i metafizičkim. Međutim, poezija Senke Marić je duboko ukotvljena u svijet realnosti u kojem je, prema riječima autorice, „književnost često stvarnija od realnog svijeta. ${ }^{(9)}$ Njena zbirka pjesama Do smrti naredne podijeljena je na četiri ciklusa koji su zaokruženi sljedećim naslovima: „Je li se ovako umire?“, „Talog“, „Motifs féminin“ i „Dobro je“. Svaki od njih pojedinačno, kao i njihovo jedinstvo cjeline, ogoljen je od maske uloga koje čovjek igra na pozornici stvarnosti. Također, odnos stvarnosti i književnosti se u pogledu iznutra iz zbirke pjesama Senke Marić može

7 Isto.

8 Marić, S. (2016) Do smrti naredne, Tešanj: Izdavačko-štamparska kuća „Planjax Komerc doo“.

9 Salčinovič, E. nav. internet izdanje. 
vidjeti kao ničeanski ples dionizijskog ili principa haosa i apolonijskog ili principa reda, pri čemu je književnost bliža apolonijskoj spoznaji. To znači da u vrtložnom kretanju života i bitka, te u plesu života i smrti ili Erosa i Tanatosa, književnost predstavlja instinkt, nagon i koncept života i stvaranja. Književnost se na taj način postavlja na žensku liniju. Metaforički rečeno, književnost dobiva ulogu majke u matrilinearnom ciklusu priče o sopstvenom stvaranju sebe u tijelu i duši žene kroz (žensko) tijelo pjesme pjesničke stvarateljke, i tako iznova od smrti $d o$ smrti naredne. U određenom smislu tako i poezija poprima svojstva romantičarske sile s kojom se pjesnikinja rađa, i to svakom pjesmom uvijek iznova. Pjesnikinja u ulozi lirskog subjekta ili glavne akterke pjesme kao te nesavladive sile stvaranja i života, nasuprot umiranju i smrti, aktualizira sopstveno stvaranje i (p) ostanak kako pjesnikinjom, tako i ženom. U genezi sebe, i/ili pjesnikinje i/ili žene, od pjesme do pjesme naredne, ona stvara i mit o Bogu Majci (Bog, kao Jedan, je Majka - God the Mother), mada je ,vjera“ njenih pjesama ateistička. Pjesnička ,ja“ je izopćena od svijeta, pa i onda kada se sjedinjava s nekim njegovim elementima, a čak i kada poprima atribute Boga Majke. Lirska akterka je skoro uvijek u drugosti u odnosu na svijet, neki muški subjekt, sam život, te i na samu sebe u smislu odnosnosti svoga duha i tijela. I onda kada u jednini neke pjesme drugost nje jedne nema, već se u sferi metafizičke ljubavi dvoje u jedinstvu postavljaju na plan određene pozitivne mitologeme drugosti u odnosu na svijet, kao, naprimjer, u pjesmama „Na livadi“ i „Danas“, koje u ciklusu „Talog“ i indikativno slijede jedna iza druge, to je „uslovljen[o] nepostojanjem sutra“10, ili se, na neki drugi način, ,događa“ u procjepu postojanja, naprimjer, u sjećanju ili zamišljanju. Ipak, kada se događaju, fantazme su tu u racionalnom konstruktu. Njima se najčešće daje smisao trenutku i/ili životu. Također, fantazma u poeziji Senke Marić često ima upravo suprotno značenje od samog značenja fantazme. Jedan od takvih primjera iščitava se u pjesmi paradoksalnog naslova „Važnost fantazme“, ponovo u ciklusu „Talog“‘. Važnost fantazme iz vizure žene u toj pjesmi nije u metafizičkoj ljubavi, već u erotskom nagonu, seksualnoj požudi i seksu-zbog-seksa kao izrazu, pa i kriku života nasuprot smrti. Erotsko se tako u principu života mitologizira u pravcu ljubavi, i to fizičke ljubavi. Eros je samotranscendirajuća moć, takoreći, nagona življenja u emancipaciji života. Nagon ženskog življenja ispisuje se, naprimjer, i slikom ekstatičnog plesa pjesničke akterke u ljetnoj haljini, vjerovatno na početku jeseni (da ugodi njemu, ali i da se osjeti živom, jer živa je, živa je, živa ${ }^{11}$ ), u pjesmi „Ples“ koja

10 Marić, S. nav. djelo, str. 38.

11 Isto, str. 29. 
u pjesničkom nizu zbirke slijedi nakon „Važnosti fantazme“, te time i samostalno i u svojevrsnom dijalogu s tom pjesmom dopunjuje značenje fantazme i njene važnosti $u$, takoreći, poetskom leksikonu savremenog ženskog življenja i umiranja Senke Marić. Taj niz fantazme, u slijedu nakon „Važnosti fantazme“ i „Plesa“, upotpunjuju i pjesme „Na obali“ i „Kao na filmu“. Svaka pjesma je ujedno i priča sama za sebe i dio jedne priče $D o$ smrti naredne. Isto vrijedi i za taj niz pjesama fantazme, između ostalih toga modusa, kao i za svaki ciklus zbirke pojedinačno, a onda i za zbirku u cjelini. I „Važnost fantazme“ i „Ples“ i „Na obali“ i „Kao na filmu“, svaka pjesma na svoj način, stvara fantazmu s uporištem u realnosti. „Na obali“ je pjesma o dvoje koji već odavno nisu dvoje u jedinstvu, već zasebne jednine kako unutar realnosti tako i unutar fantazme u kojoj, ni za trenutak, nema odsustva realnosti jer „kasno je već da se pokuša“12 išta. Ton pjesme je tužan i ima oznaku smrti u različitim varijacijama. U minus postupku i pjesme i njene fantazme nalazi se želja za tim da se možda pokuša nešto kako za nama ne bi uvijek ostajale tišine i/ili ,mjesta kojima ne pripadamo“13. Pjesma „Kao na filmu“ se u jednom od njenih mogućih čitanja ostvaruje kao svojevrsna fantazma iz minus postupka pjesme „Na obali“. Neki „on“ će možda pokušati nešto i ,spasiti“"14 ženu u ulozi pjesničke glavne junakinje, ili obratno, pjesničku junakinju u ulozi žene. „Kao na filmu“ je njena kratka priča u stihovima:

Ako osluhneš

tišina će te navesti na moj trag

Prepoznat ćeš me po dlanovima

u koje sam urezala

sve dosadašnje poraze

(linija ljubavi naglo presječena

ožiljkom iz djetinjstva)

Možda ćeš me tada spasiti

i ljubiti

onako filmski

- glava zabačena unazad dok

vijori kosa. ${ }^{15}$

12 Isto, str. 30.

13 Isto.

14 Isto, str. 31.

15 Isto. 
Međutim, „Kao na filmu“ dolazi nakon pjesme „Na obali“, kako u pjesničkom nizu zbirke tako i metaforički nakon smrti te pjesme, pa je „Kao na filmu“ i neka nova fantazma i neka nova mogućnost realnosti i života. Za razliku od pjesme „Na obali“, čija je fantazma o (ne)mogućnosti prošlosti, a kao takva je i groteskna, pjesma „Kao na filmu“ i njena fantazma okrenuti su ka budućnosti, a njen ton je kombinacija tragike i komike, također, u kategoriji groteske. Žena je tu sama i usamljena, kakva je većinom žena iz historije priče u stihu Do smrti naredne Senke Marić. Njene pjesme ispisuju iskonsku matrilinearnu priču o ženi. Naime, žena je predodređena prvom ženom i njenim grijehom. Taj grijeh je u jednom značenjskom nivou i ožiljak iz djetinjstva iz pjesme „Kao na filmu“ kojim je obilježena žena. Tako, recimo, pjesma „Ugriz“ iz ciklusa „Motifs féminin“ priča sljedeću priču:

To voće je uvijek jabuka

da ne moraš trošiti dodatne riječi

na simboliku

Ugriz je urezan u tvoju prirodu

Ona je svakako došla prije tebe

predodredila tvoj put

tvoj pad

Ionako

ako zagrizeš u nešto tvrđe

niko te neće razumjeti. ${ }^{16}$

Žena u ulozi lirske junakinje (ili lirska junakinja u ulozi žene), ipak, i uprkos svemu, zagriza u nešto tvrđe i postaje izopćenija od same žene, a time i od svoje stvoriteljice/(pra)majke, ali i jača - postaje pjesnikinjom. Ona sama sebe stvara od pjesme do pjesme naredne, od smrti do smrti naredne.

Prvi ciklus pjesama koji nosi naslov u znaku pitanja „Je li se ovako umire?" predstavlja početak stvaranja paradoksalan kontekstu i konceptu smrti iz tog naslovnog pitanja. Taj ciklus je i najkraći u zbirci. Njega čine četiri pjesme pod naslovima: „Smrti““, „Post-op“, „Hronika jedne bolesti“ i ,Tijelo ovo“. Metaforički rečeno, prvi ciklus predstavlja riječ koja bijaše na počet$k u$. Ta riječ poetski ispisuje suočenje sa smrću uslijed bolesti karcinoma dojke pjesničkog ženskog lica. Lirska akterka se u iskustvenoj stvarnosti, takoreći, preživljavanja sopstvene smrti

16 Isto, str. 60 . 
i umiranja dijelova sopstvenog tijela izjednačava sa samom pjesnikinjom. Naime, Senka Marić pjesnički ogoljava intimno i blisko iskustvo smrti svoga tijela i život nakon smrti određenih dijelova svoga ženskog tijela u ožiljcima, te književnom riječi nastoji da shvati i prihvati svoju novu stvarnost, nadljudsko svede na nivo ljudskog i da se poslije te smrti iznova stvori. U duhu takve riječi prva pjesma prvog ciklusa koja se obraća smrti, na što upućuje i njen naslov „Smrti“, počinje inkantacijom pjesničke misli Maka Dizdara iz njegove pjesme pod nazivom „Svatovska“. Pjesnička akterka, žena s početka pjesme koja je u potrazi za biljkom ,što rak liječi“'17, u čijoj ulozi se javlja sama pjesnikinja, svojom poetikom prenosi svoje psihičko stanje na prirodu i ostatak svijeta. Njena nutarnjost u dekonstrukciji time postaje postupak konstrukcije pjesme. Upotrebom elemenata takozvane „pathetic fallacy“ i postupcima mitologizacije ta pjesnička žena transcendira u Boga Majku. Međutim, u krajnjem ishodu i postupkom (anti)transcendencije se ispostavlja da su konture mitološkog upisane u autobiografsko jastvo pjesnikinje, čime poezija Senke Marić, već na samom početku zbirke, postaje i mit o stvaranju pjesnikinje. Pjesma „Smrti“ završava autoteličkom inkantacijom iz Dizdarove pjesme preformulisanom u pitanje: „Smrću mojom hoće li umrijeti svijet?“. Ta pjesma Senke Marić funkcionira kao inkantacija prvog ciklusa, koji, također, na osobit način, djeluje kao inkantacija cijele zbirke. Pitanje: ,Je li se ovako umire?“ ponavlja se unutar pjesme „Hronika jedne bolesti“ koja bolnom iskrenošću ispovijeda o emocionalnom i tjelesnom suočavanju s bolešću karcinoma dojke i preživljavanju života ispunjenog sopstvenim umiranjem. Prvi ciklus i jeste lirska hronika preživljavanja bolesti žene. To je njena kratka priča o historiji bolesti sopstvenoga tijela, lirizirani dnevnik preživljavanja svog umiranja i zapis o tome kako je nadživjela sopstvenu smrt. Iznad svega, taj ciklus pjeva o životu i pjeva životu iz pozicije neposrednog iskustva smrti. Četiri pjesme koje ga čine su, svaka na svoj način, suočenje sa smrću, a time i sa životom jer život jedino u suočenju sa smrću dobiva pravo značenje. Na prvom frontu suočenja sa smrću su njena koža i tijelo. Prvo će joj otkinuti trećinu sise ${ }^{18}$, a zatim će joj odsjeći obje sise ${ }^{19}$. „I onda“, ona kaže,

... čekanje

i dani dugi i bijeli

a kičma moja od kamena, od mermera

17 Isto, str. 7.

18 Isto, str. 9.

19 Isto, str. 10. 


\section{SELMA RALJEVIĆ}

drži me uspravno i ne popušta

ne priznaje

to rastakanje tijela, to bolno fragmentiranje

upućivanje na njegovu nesavršenost

lomljivost

krhkost

napuklost...

$\mathrm{Ja}-$ mehanizam u kvaru. ${ }^{20}$

Tendencijom mehanizma preživljavanja u suočenju s umiranjem sebe u vidu karcinoma dojke ispostavlja se podnošenje na način „kao da se dešava nekom drugom“21. Pjesnikinja kroz poeziju sama sebe stvara dok se u stvarnosti kao modalitetu poezije njen(a) alter ego rastvara i razjedinjuje sam(a) u sebi i sam(a) od sebe. Njeno biće se u svijetu realnosti rastače od njenog tijela, pa je ishodište poezije i književnosti stvaranje. Književnost je možda jedina Bog Majka u poeziji kao krajnjoj realnosti Do smrti naredne Senke Marić. Pjesnička ,ja“ Senke Marić pjesmom pokušava da stane u svoju kožu ${ }^{22}$ i prisjeća se, gutajući bol jer joj je koža uska - ,zato sve to (naravno!) - / i liči na kožu žene“ - koliko žudi „do starosti / dovući / tijelo / ovo“23.

Život u cjelini je u viđenju Senke Marić „talog što ostane iza

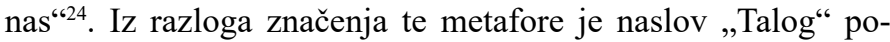
sljednje pjesme iz drugog i najdužeg ciklusa ujedno i naslov toga dijela zbirke. Pjesme iz drugog ciklusa progovaraju o ljubavi, toj možda najstarijoj pjesničkoj preokupaciji, ali nekom novom ženskom osjećajnošću koja je, s jedne strane, duhovna i metafizička, a s druge, tjelesna i erotska. Ljubav u svim tim vidovima je jedan od osnovnih sastojaka taloga, odnosno života, i to i onda kada ljubavi u svim njenim oblicima nedostaje u životu, i onda kada ljubavi u svim vidovima ima, ili kada ljubavi ima tek u određenim tragovima. Zbog toga, vjerovatno, nije slučajno da se na samom kraju pjesme „Pod prijetnjom smrću“ u ciklusu „Talog“ dešava stih „Do smrti naredne“"25 koji ima funkciju i naslova zbirke. Ljubav u „Talogu“, i pjesmi i ciklusu u zbirci Senke Marić, a u posudbi, recimo, višestruke književne misli transnacionalne turske spisateljice Elif Šafak (Elif Shafak / Elif

20 Isto, str. 10-11.

21 Isto, str. 12.

22 Isto, str. 13.

23 Isto, str. 14.

24 Isto, str. 45.

25 Isto, str. 24. 
Şafak), jeste stvar koja je prisutna svojom odsutnošću onda kada je nema. Iako je i u „Talogu“ i u zbirci Do smrti naredne u cjelini ostihovljena ljubav u savremenom svijetu - i to u nivou ljubavi između partnera to je, u ovom slučaju, emocionalna i fizička ljubav jedino između muškarca i žene - ljubav je ženskom linijom oblikovana prošlošću i historijom. Prošlost je modalitet sadašnjosti, a historija je kao njegova priča (HIStory) neizbježno utkana u njenu priču (HERstory). Pjesnička ,ja“ je savremena žena koja se mijenja u odnosu na ženu iz prošlosti, ali je ona i dalje obilježena bremenom historije. Ona je žena kao jedna i, istovremeno, sve žene u jednoj. Društvo u kojem lirska žena živi do smrti naredne se sporije mijenja (ili se umnogome ne mijenja nikako) i stagnira u odnosu na progresivnu misao pjesničke ,ja“ pjesnikinje. Međutim, i ona sama je često u raskolu između sebe iznutra i izvana - između svoje misli i njenog izraza, između svoga biti i ne biti i samog značenja bivanja i nebivanja $u$ sopstvenom ključu. Osim toga, njeno breme je i strah. Između ostaloga, to je strah od mnogih oblika smrti, pa ona u pjesmi „Pod prijetnjom smrću“ kaže:

Zar tako teško je odreći se svih tih sati

što ih u svojoj nesmotrenosti nazvasmo ljubavlju?

Zar ne znaš da to je samo

strah od tijela koje se raspada u zemlji

zato ga je bilo prijeko potrebno

oživjeti

samo još jednom

jer ko zna

možda već sutra

taj užasni

neizdrživi

vodoravni

položaj

I tišina

Tišina guste zemlje kroz koju ne prolazi zrak

Zato dahćemo glasno. ${ }^{26}$ 
Klišetizirane slike ${ }^{27}$ ljubavi, kako ih sama pjesnička/pjesnikinja ,ja“" naziva, dio su taloga života i kao takve su životne i životvorne. Međutim, nova osjećajnost ${ }^{28}$ pjesnikinjinog izraza u smislu originalnog emocionalnog samootkrivanja razbija bilo kakvu klišetiziranost pjesničke slike. U duhu te nove osjećajnosti, između ostaloga, i samoće predstavljaju tvorbeni princip straha, ali i ženskog bremena u određenom smislu. Naime, tkivo savremene poezije Senke Marić čini i tradicija, pa njena lirska žena nije u potpunosti oslobođena matrilinearnog nasljeđa žene kao „slabijeg spola“ i podređenog pola u odnosu na muškarca. Njena sreća je često uvjetovana akcijom i bivanjem muškarca, a ona sama, dok u topografiji svojih tišina čeka, većinom se nalazi u poziciji stagnacije i nebivanja. Kao takva je tek napola stvarna. O svojoj nepodnošljivoj lakoći postojanja kaže:

Ne mogu se sjetiti kako se smije

kako se smije

kada je lako živjeti. ${ }^{29}$

Ona je, također, nezaštićena i nejaka i kao žena i kao pojedinac u vrlom novom svijetu jer nije imuna na bolesti savremenog društva. Žena u pjesmi „Naše bolesti“ nema snage da se „uzaludnim gestom dizanja ruku“30 zaštiti od tih bolesti društva: konflikta realnosti $i$ želje, neuroza, anksioznih poremećaja, neusklađenosti ida i ega ${ }^{31}$, iluzije stvarnosti i alternativnih činjenica, da upotrijebimo trumpovsku metaforu. I sve je to, opet, dio taloga. Međutim, lirska žena u transcendenciji pjesnikinje ima snage da progovori, pa time i da digne glas, nadvlada strah od življenja i da živi riječju do smrti naredne.

Upravo, pjesma „Talog“, svojom pozicijom i feminističkim motivom društvenog taloga ženske uloge koja se oblači kao uredno

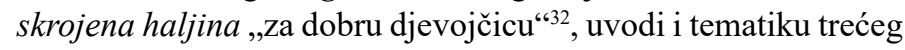
ciklusa koji je naslovljen „Motifs féminin“. U tom dijelu zbirke prelamaju se glasovi ženskog poliglasja kroz historiju u vidu njene priče, kao i kroz književnost i druge oblike ljudske ili, bolje reći, ženske pojavnosti, i isprepliću s intimom pjesničkog ženskog lica. Ona, pjesnička protagonistica ili lirska akterka ili (is)kazateljica pjesme, je u „Motifs féminin“ i slaba i jaka,

\section{Isto.}

28 Kelly, A. „Dialectic of Sincerity: Lionel Thrilling and David Foster Wallace“, 17. oktobar 2014., 2. septembar 2017., http://post45.research.yale.edu/2014/10/dialectic-of-sincerity-lionel-trilling-and-david-foster-wallace/

29 Marić, S. nav. djelo, str. 25.

30 Isto, str. 42.

31 Isto.

32 Isto, str. 45. 
i bolna i otupjela od boli, i cjelovita i podijeljena, i sve žene i ni jedna cijela, i mitologizirana i sasvim stvarna, s pozicijom i u životu koji se živi i u životu koji se ne živi. Pjesme iz trećeg ciklusa slobodnim i golim ženskim glasom izgovaraju priču ženske strane svijeta. Ta priča je matrilinearna, što znači da je postavljena na žensku liniju. Priča, međutim, nije linearna, nije hronološka, već je nelinearno razbacana u fragmente. Paradoksalno, u priču je utkana hronologija ženske priče kroz historiju u vidu njene priče. Njene niti u sitnom vezu $u^{33}$, da se poslužimo metaforom iz posljednje pjesme iz ciklusa „Motifs féminin“ pod nazivom „Niti“, uvezuju ženu iz tradicionalnog patrijarhalnog sistema, njenu šutnju i trpljenje, i ženu iz savremenog društva, još uvijek neoslobođenu i još uvijek neoslobođeno zadatih okvi$r a^{34}$ tradicije. Ta žena lirikom, odnosno pričom i književnošću prevladava „zadati“ strah žene i njeno (ne)postojanje u tišinama. Ona progovara i o našim majkama i nasljeđu te šutnje i trpljenja. Time progovara i protiv tog nasljeđa, i to kao prvim ženskim koracima/riječima, kao da tek pokušava hodati/govoriti (i živjeti), kao da svežena u njenom utjelovljenju tek progovara jer „I ne slože se ta slova u riječi / jer uši i nisu navikle na taj zvuk ${ }^{635}$. Ona samu sebe izriče u vidu rađanja. Ta „Ona“ postaje pjesnikinjom. U unutarnjem razgovoru lirske žene s pjesnikinjom u sebi u pjesmi „Razgovor“ između njih „dvije“ slažu se slova u riječi:

Znaš da moraš više

Da daš ili da ti se da?

Izgubljena u potrazi za odgovorom

Još uvijek dopuštaš da te mimoilaze dani

... što samo ne probaš da živiš

tek tako

bez prevelike buke

pusti kosu

pusti ruke niz tijelo

dodaj kakav osmijeh

i počni o pticama i cvijeću

o bilo čemu

samo ne o mraku iznutra

33 Isto, str, 65.

34 Isto, str. 64.

35 Isto. 
Šta čekă̌?

Ne skreći pogled!

Čega se bojiš?

govori ona

ona kojoj više ne mogu prodati svoje laži

Ona - iz ogledala

Ona koja se uopće ne plaši da spava sama. ${ }^{36}$

U svemu tome, u tišinama i njenim procjepima, u paradoksima - i kada je kao žena „slabija“ i „slabiji spol“, i kada se sublimno ispostavlja jakom u slabostima $\mathrm{i} / \mathrm{ili}$ sopstvene bolesti $\mathrm{i} /$ ili svih bolesti društva i svijeta, pa i kada se na neki način ispostavlja „snažnijim spolom“, Ona, lirska (sve)žena, književna hroničarka ženske strane svijeta - Pjesnikinja, ispušta slovo Do smrti naredne da otupi „oštricu / što pod rebrima živu ranu već pravi““37. To slovo je sveženski

uzdah kojim smo prešutjele

sve ovo vrijeme

savršene majke

podatne ljubavnice

izvrsne kuharice. ${ }^{38}$

Zbirka u cjelini ispisuje autentičnu žensku ontologiju kako života, tako i smrti, što se u posebnom ključu tematizira i u posljednjem, četvrtom ciklusu „Dobro je“. U njemu se u vidu svojevrsne završne ili zaključne riječi objedinjuju i radosti i tuge, i sreće i nesreće, i svijetla i tamna strana življenja ne kao dva suprotna principa, već kao isprepletene životne neminovnosti, gdje je i smrt neminovnost života. Topografija nutarnjosti u dekonstrukciji upotrebom elemenata ,pathetic fallacy“ s početka zbirke transcendira u topografiju nutarnjosti u konstrukciji na njenom kraju, pri čemu je i dekonstrukcija dio konstrukcije po matrilinearnoj liniji Majke Zemlje. Tako, naprimjer, Ona, dok sa svog prozora gleda komšijinu japansku jabuku, koja ,[1]agano drhti na vjetru / dok lopte je sočne / blještave na pozadini od sivog Huma / vuku prema zemlji ${ }^{\text {“39 }}$, prošaptava: „Sestro / ...izdrži još malo / otpast će! $!^{640} \mathrm{Na}$ osnovu svega toga, ako je značenje živo-

36 Isto. str. 61-62.

37 Isto, str. 64.

38 Isto.

39 Isto, str. 76.

40 Isto. 


\section{SELMA RALJEVIĆ}

ta u smrti, a jezik mjera života, da se poslužimo parafrazom rije$\check{c ̌ i}^{41}$ Toni Morison (Toni Morrison), prve žene afričko-američkog porijekla koja je dobila Nobelovu nagradu za književnost, Senka Marić poezijom Do smrti naredne jezički ogoljava ženski bitak života i stvara poetiku ženskog življenja života bliskog smrti, a onda i životnijeg života, u sopstvenom izrazu.

\section{LITERATURA:}

Anderson, B. (1998) Nacija: zamišljena zajednica, Beograd: Plato.

Kelly, A. Dialectic of Sincerity: Lionel Thrilling and David Foster Wallace, 17. oktobar 2014., 2. septembar 2017., http://post45.research. yale.edu/2014/10/dialectic-of-sincerity-lionel-trilling-and-david-foster-wallace/

Marić, S. (2016) Do smrti naredne, Tešanj: Izdavačko-štamparska kuća Planjax Komerc doo.

Morrison, T. „Nobel Lecture“, 2. septembar 2017., https://www.nobelprize.org/nobel_prizes/literature/laureates/1993/morrison-lecture.html

Nafisi, A. (2014) The Republic of Imagination: America in Three Books, New York: Viking Penguin.

Salčinović, E. Možda bismo odustali od ljubavi: Intervju sa Senkom Marić, Oslobođenje, 6. februar 2017., 2. maj 2017., http://www.oslobodjenje.ba/kun/umjetnost/mozda-bismo-odustali-od-ljubavi/193135

Spirit of Bosnia / Duh Bosne br. 2, godište 9, 2. septembar 2017., http://www.spiritofbosnia.org/bs/volume-9-no-2-2014april/itsgood/?output=pdf

41 Morrison, T. „Nobel Lecture“, 2. septembar 2017., https://www.nobelprize. org/nobel_prizes/literature/laureates/1993/morrison-lecture.html 


\title{
SELMA RALJEVIĆ
}

\section{Selma Raljević}

Džemal Bijedić University in Mostar, Faculty of Humanities Department for English Language and Literature,

Mostar, Bosnia and Herzegovina

\section{A BRIEF HERSTORY OF LIVING AND DYING IN A COLLECTION OF POEMS UNTIL THE NEXT DEATH BY SENKA MARIĆ}

\begin{abstract}
Senka Marić, an acclaimed Bosnian and Herzegovinian poetess, has written a brief "herstory" of female living and dying in her 2016 collection of poems Until the Next Death. Unlike history - seen as HIStory, meaning that history is mainly written by men - HERstory reveals a woman's side of the world through her personal story. Until the Next Death is, in many ways, an autobiographical collection, so it can be seen as a poetic memoir of Senka Marić. One of its many poetic levels is her own genesis, both as a poetess and a woman. Also, it could be seen as a lyrical novel depicting her female ontology. Accordingly, this paper analyses the concepts of female "being" and "not-being" in Senka Marić's book Until the Next Death, as well as the elements of autobiographisation and mythologisation of herstory, including elements of matrilineality in all these cases.
\end{abstract}

Key words: Senka Marić, herstory, Until the Next Death, female ontology, autobiographisation, mythologisation, matrilineality

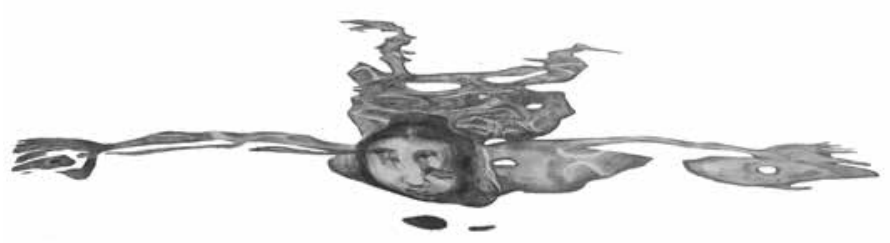

Ивана Живић, Kocmyp, цртеж, графитна оловка на папиру, 100 х 70 цм, 2017. 